\title{
STIMULAT AUXIN ALAMI DAN INTERAKSINYA DENGAN NPK ANORGANIK UNTUK MEMACU PERTUMBUHAN AWAL BIBIT DAN MENINGKATKAN HASIL TANAMAN BAWANG MERAH (Allium ascallonicum L)
}

\section{NATURAL AUXIN STIMULATOR AND THE INTERACTION WITH NPK ANORGANIC TO STIMULATE EARLY GROWTH AND INCREASE OF SHALLOT PLANT YIELD (Allium ascalonicum L)}

\author{
Palupi Puspitorini ${ }^{1)}$ dan EkoWahyu Budiman ${ }^{1)}$ \\ 1) Fakultas Pertanian Unisversitas Islam Balitar Blitar \\ Email: puspitorini.palupi@gmail.com
}

\begin{abstract}
ABSTRAK
Penelitian ini mempunyai tujuan untuk mengetahui durasi perendaman bibit dengan auxin alami dan dosis pupuk NPK yang tepat pada pertumbuhan dan hasil tanaman bawang merah (Allium ascalonicum L). Dalam budidaya bawang merah sering dijumpai pertumbuhan benih yang lambat disebabkan karena faktor dalam bibit (endogenous factor) yang merugikan karena akan berdampak pada serangan penyakit busuk umbi. Maka mempercepat munculnya tunas dengan perlakuan pemberian auxin dan pemberian pupuk NPK ini diharapkan akan diperoleh bibit yang segera tumbuh supaya dapat berproduksi dalam keadaan sehat. Pada penelitian ini akan dikaji bagaimana mempercepat pertumbuhan bibit bawang merah dengan perendaman cepat dalam auxin alami yang diinteraksikan dengan pemberian pupuk NPK. Penelitian disusun dalam RAK faktorial dengan 2 faktor sebanyak 3 x ulangan. Faktor 1 adalah perlakuan lama perendaman bibit bawang merah (D), yang terdiri dari D0 = tanpa perendaman , D1 = perendaman 0,5 jam, D2 = perendaman $1 \mathrm{jam}, \mathrm{D} 3=$ perendaman 1,5 jam, D4 = perendaman 2 jam. Sedangkan faktor kedua adalah pemberian pupuk NPK, $\mathrm{P} 1=100 \mathrm{~kg} / \mathrm{ha}, \mathrm{P} 2=200 \mathrm{~kg} / \mathrm{ha}, \mathrm{P} 3=300 \mathrm{~kg} / \mathrm{ha}$. Variabel yang diamati adalah tinggi tanaman, jumlah batang/rumpun, bobot segar bawang merah/rumpun, jumlah umbi bawang merah/rumpun. Data dianalisis dengan menggunakan Anova dan uji DMRT 5\%. Hasil Penelitian didapatkan bahwa ada pengaruh interaksi nyata antara perlakuan D (lama perendaman) dan P (dosis pupuk NPK) pada variabel tinggi tanaman, jumlah batang/rumpun, bobot segar bawang merah/rumpun dan jumlah umbi/rumpun. Perlakuan terbaik adalah D4P3 yaitu perendaman bibit bawang merah selama 2 jam dengan pemupukan NPK anorganik $300 \mathrm{~kg} / \mathrm{ha}$.
\end{abstract}

Kata kunci: bawang merah; auxin alami; bibit bawang merah; pupuk NPK

\section{ABSTRACT}

The aims of the study was to determine the duration of bulb dipping with natural auxin on the growth and yield of shallot (Allium ascalonicum L). In shallot cultivation, it is found that the slow growth of bulb is caused by the factors in the bulbs (endogenous factors) because it will impact on bulb rot disease. Then accelerating the emergence of shoots with the treatment of auxin and NPK fertilizer, it is hoped that the bulbs will grow well so that they will be harvested in a healthy condition. In this research, we will study how to accelerate the growth of shallot bulbs with rapid immersion in natural auxin which is interacted with NPK fertilizer. The research was arranged in a 
factorial randomized block design with 2 factors and repeated 3 times, where the first factor was the treatment was the length of dipping the shallot seeds. (D). consisting of $D 0=$ without dipping, D1 = dipping 0.5 hours, D2 = dipping 1 hour, D3 = dipping 1.5 hours, D4 = dipping 2 hours. While the second factor is the provision of NPK fertilizer, $P 1=100 \mathrm{~kg} / \mathrm{ha}, P 2=200 \mathrm{~kg} / \mathrm{ha}, P 3=300 \mathrm{~kg} . \mathrm{ha}$. The variables observed were plant height, number of clumps / plant, fresh weight of shallots / plant, number of shallot bulbs / plant. Observation data were analyzed by ANOVA and 5\% DMRT test. The results showed that there was a significant interaction effect between $D$ and $P$ treatment on the variable plant height, number of clumps/plant, fresh weight of shallots / plants and number of tubers / plants. The best treatment is D4P3, which is soaking shallot seeds for 2 hours with $300 \mathrm{~kg} / \mathrm{ha}$ of inorganic NPK fertilization.

Key words: shallots; natural auxin; shallot bulbs; NPK fertilizer

\section{PENDAHULUAN}

Tanaman bawang merah (Allium ascalonicum L) adalah komoditas strategis di Indonesia dan merupakan salah satu komoditas bernilai tinggi dan banyak dibutuhkan oleh sebagian masyarakat Indonesia utamanya sebagai bumbu masakan. Produksi bawang merah 2016 adalah 1,45 juta ton dan meningkat pada 2017 yaitu 1,47 juta ton (BPS 2018). Prospek tanaman bawang merah sangat baik karena daya konsumsi masyarakat yang tinggi.

Secara alamiah tanaman mengandung hormon yang diistilahkan dengan hormon endogen sebagai contoh hormon Giberelin, Sitokinin dan Auksin. Hormon endogen dapat berkurang apabila pola budidaya tanaman kurang sesuai dengan standardnya. Hal ini menyebabkan pertumbuhan vegetatif dan generatif kurang maksimal. Gejala kekurangan hormon ini adalah terjadinya kerontokan pada bunga dan buah, pertumbuhan terlambat, ukuran buah kecil. Kandungan zat pengatur tumbuh alami sangat sedikit di dalam tubuh tanaman dibandingkan dengan kebutuhan tanaman untuk tumbuh dengan baik, namun pemakaian dengan dosis berlebih malah akan menghambat tumbuhnya bibit.

Ada 3 cara pemakaian ZPT yaitu Concentrated Solution Dip Method (pencelupan cepat), Dilute Solution Soaking Method (dipping), dan Commercial Powder Preparation (pasta). Untuk ZPT berbentuk cair seperti air kelapa dapat digunakan dengan cara perendaman. Diketahui bahwa air kelapa mengandung unsur hara, vitamin dan terutama adalah hormon auksin, giberelin dan sitokinin yang mempunyai fungsi memacu 
pertumbuhan jaringan tanaman, meningkatkan metabolisme dan berpengaruh pada reaksi respirasi. Pada beberapa studi dikatakan bahwa durasi perendaman benih berpengaruh pada proses perkecambahan. Air akan berimbibisi ke dalam kulit benih dan akan meningkatkan turgiditas sel sebelum terjadi pembelahan. Benih akan berkecambah setelah terjadi pecah kulit yang disebabkan benihmembengkak akibat peristiwa imbibisi (Juhanda, 2013). Sedangkan apabila benih tidak direndam akan menyebabkan dinding sel impermeabel, dan oksigen akan mengalami hambatan masuk ke dalam benih (Mahadi, 2011). Air berfungsi sebagai alat transportasi dan membantu dalam reaksi kimia pembongkaran cadangan makanan yang akan membantu tumbuhnya calon tanaman menjadi tanaman. Pembongkaran cadangan makanan akan berlangsung sangat lambat sesuai fungsi air yang berpengaruh pada reaksi biokimia dan kerja enzim.

Pupuk majemuk mengandung unsur NPK dan berfungsi meningkatkan pertumbuhan dan hasil tanaman dengan perbandingan 16:16:16. Pemberiannya ke tanah diharapkan akan menambah konsentrasi unsur hara di dalam tanah. Rekomendasi pupuk NPK ini untuk bawang merah umumnya adalah 150-300 kg N/ha, $90=180 \mathrm{~kg}$ P/ha dan 50-100 kg K/ha bervariasi dosisnya tergantung varietas yang ditanam, musim dan jenis tanah. Penelitian oleh Hasibuan (2010) bahwa pupuk NPK meningkatkan jumlah daun, diameter umbi, bobot basah dan bobot keringnya. Menurut Sumarni (2012), perlakuan dengan pupuk hayati akan meningkatkan hasil tanaman bawang merah dan dipengaruhi oleh pemberian dosis NPK. Pada beberapa variabel menunjukkan hasil yang baik. Dosis NPK majemuk antara $730-1.300 \mathrm{~kg} / \mathrm{ha}$. Islam, et al. (2007) mengatakan bahwa dosis pemupukan berpengaruh positif pada tanaman bawang merah. Pemberian unsur N, P, K, S dosis $100 \mathrm{~kg} / \mathrm{ha} \mathrm{N}, 80 \mathrm{~kg} / \mathrm{ha} \mathrm{P}$, $50 \mathrm{~kg} / \mathrm{ha} \quad \mathrm{K}$, dan $30 \mathrm{~kg} / \mathrm{ha} \quad \mathrm{S}$ dapat memperbaiki hasil umbi. Dosis yang ditingkatkan tidak lagi menambah hasil tanaman (Amin, et al. 2007).

\section{METODE}

Penelitian disusun dalam RAK Faktorial 2 faktor dengan tiga ulangan, faktor pertama yaitu perlakuan durasi perendaman bibit bawang merah varietas Thailand dalam auxin alami (air kelapa muda) (D) yang terdiri dari D0 = tanpa perendaman, D1= lama perendaman $0,5 \mathrm{jam}, \mathrm{D} 2=$ lama perendaman 1 jam, D3= lama perendaman 1,5 jam, D4 = lama perendaman 2 jam. Sedangkan faktor 
ke-2 adalah dosis pupuk NPK merah/rumpun, jumlah umbi bawang anorganik, $\mathrm{P} 1=100 \mathrm{~kg} / \mathrm{ha}, \mathrm{P} 2=200$ $\mathrm{kg} / \mathrm{ha}, \mathrm{P} 3=300 \mathrm{~kg} / \mathrm{ha}$.

Variabel pengamatan yaitu tinggi tanaman bawang merah, jumlah merah/rumpun. Data dianalisis dengan Anova 5\% pada semua variabel yang diamati dan apabila interaksi nyata akan diuji dengan Duncans 5\%.

batang/rumpun, bobot segar bawang

Alur pelaksanaan penelitian disajikan pada gambar berikut.

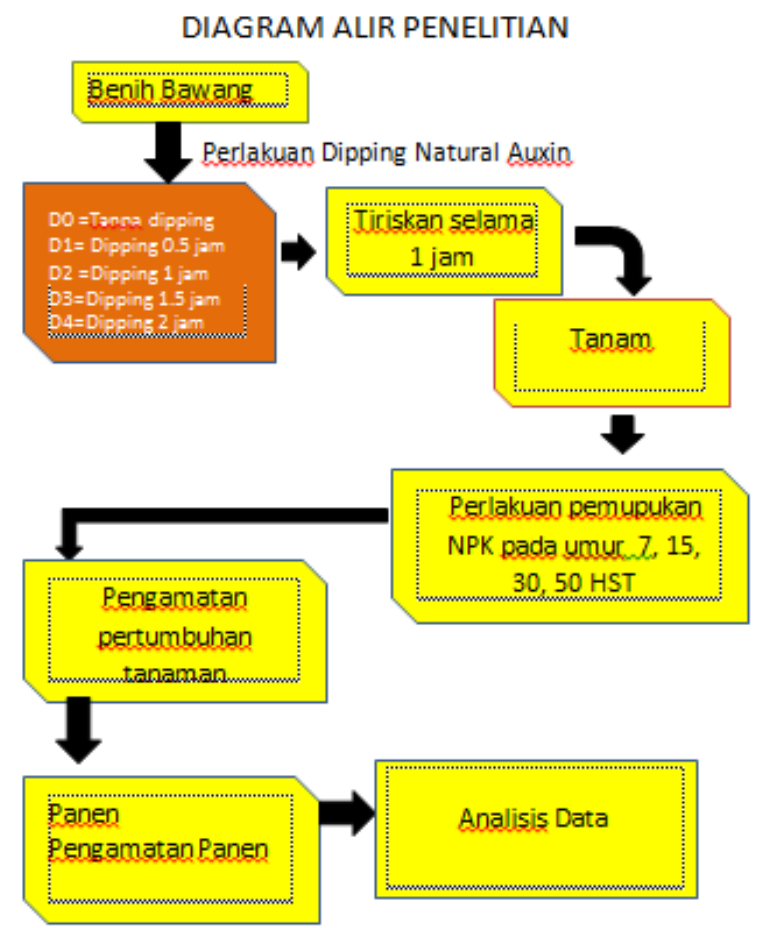

Gambar 1. Alur Penelitian

HASIL DAN PEMBAHASAN

\section{Tinggi Tanaman}

Dari hasil analisis anova didapatkan bahwa durasi perendaman auxin alami dan dosis pemupukan NPK tidak berinteraksi nyata untuk variabel tinggi tanaman bawang merah, begitu juga analisis masing-masing faktor perendaman (D) dan pemupukan (P) juga tidak menunjukkan pengaruh nyata pada pengamatan hingga 35 HST kecuali D pada umur 21 HST memperlihatkan hasil terbaik D2 yaitu perendaman selama 1 jam sebelum tanam dengan tinggi tanaman $36,22 \mathrm{~cm}$ paling baik dibandingkan dengan perlakuan lainnya (Tabel 1). 
Tabel 1. Rerata Tinggi Tanaman Bawang Merah pada Semua Umur Pengamatan

\begin{tabular}{cccccccc}
\hline \multirow{2}{*}{ Perlakuan } & \multicolumn{7}{c}{ TinggiTanaman(cm) HST } \\
& 15 & 21 & 28 & 35 & 49 & 56 & 63 \\
\hline & & & & & & & \\
D0 & $27,11 \mathrm{a}$ & $33,40 \mathrm{a}$ & $40,50 \mathrm{a}$ & $47,56 \mathrm{a}$ & $52,56 \mathrm{a}$ & $52,78 \mathrm{a}$ & $53,00 \mathrm{a}$ \\
D1 & $29,67 \mathrm{a}$ & $35,33 \mathrm{ab}$ & $41,61 \mathrm{a}$ & $47,89 \mathrm{a}$ & $52,79 \mathrm{a}$ & $53,22 \mathrm{a}$ & $50,89 \mathrm{a}$ \\
D2 & $29,22 \mathrm{a}$ & $36,22 \mathrm{~b}$ & $42,00 \mathrm{a}$ & $47,78 \mathrm{a}$ & $62,67 \mathrm{c}$ & $62,89 \mathrm{c}$ & $63,89 \mathrm{c}$ \\
D3 & $28,33 \mathrm{a}$ & $34,44 \mathrm{ab}$ & $41,33 \mathrm{a}$ & $48,22 \mathrm{a}$ & $55,89 \mathrm{a}$ & $54,33 \mathrm{a}$ & $53,56 \mathrm{a}$ \\
D4 & $27,22 \mathrm{a}$ & $34,78 \mathrm{ab}$ & $39,78 \mathrm{a}$ & $44,78 \mathrm{a}$ & $57,22 \mathrm{ab}$ & $59,78 \mathrm{~b}$ & $60,78 \mathrm{~b}$ \\
& & & & & & & \\
P1 & $28,533 \mathrm{a}$ & $34,73 \mathrm{a}$ & $40,70 \mathrm{a}$ & $46,67 \mathrm{a}$ & $52,80 \mathrm{a}$ & $53,20 \mathrm{a}$ & $52,60 \mathrm{a}$ \\
P2 & $27,933 \mathrm{a}$ & $35,40 \mathrm{a}$ & $42,03 \mathrm{a}$ & $48,67 \mathrm{a}$ & $54,73 \mathrm{ab}$ & $54,20 \mathrm{ab}$ & $55,60 \mathrm{ab}$ \\
P3 & $28,467 \mathrm{a}$ & $34,40 \mathrm{a}$ & $40,40 \mathrm{a}$ & $46,40 \mathrm{a}$ & $57,73 \mathrm{~b}$ & $58,60 \mathrm{a}$ & $60,87 \mathrm{~b}$ \\
\hline
\end{tabular}

Keterangan : Angka yang didampingi huruf sama tidak berbeda dengan uji Duncans $\alpha=0,05$

Hasil analisis pada umur selanjutnya untuk tinggi tanaman menunjukkan perbedaan nyata pada umur 49 hingga 63 HST pada perlakuan lama perendaman dalam larutan auxin alami (D) yaitu perlakuan D2 merupakan perlakuan terbaik dibandingkan yang lain. Hasil analisis pada perlakuan dosis pemupukan $(\mathrm{P})$ seperti diperlihatkan pada Tabel 1 bahwa dosis pemupukan NPK ( 300 $\mathrm{kg} / \mathrm{ha}$ ) adalah perlakuan terbaik pada variabel tinggi tanaman ini. Indikator pertumbuhan biasanya dilakukan dengan mengukur tinggi tanaman (Risva, et al., 2014). Tinggi tanaman merupakan perubahan dimensi tanaman yang disebabkan karena pengaruh metabolisme dalam tubuh tanaman. Reaksi respirasi pada tanaman akan membongkar cadangan makanan dalam benih dan menghasilkan energi yang digunakan untuk tumbuh menjadi lebih besar. Reaksi respirasi dibantu oleh hormon auxin dan gibberelin membantu pembelahan embrio (Rajiman, 2018). Dikatakan pula bahwa pemberian auxin alami air kelapa dapat meningkatkan tinggi tanaman melati putih (Khair, 2013 dalam Rajiman 2018).

Pertumbuhan tanaman juga dipengaruhi oleh faktor lingkungan yang mendukung keberhasilan peningkatan pertumbuhan. Pemupukan merupakan salah faktor lingkungan tersebut. Yuliarti (2007) menyampaikan bahwa $\mathrm{N}$ mempunyai fungsi mensintesa klorofil, protein dan asam amino. Secara menyeluruh interaksi unsur ini dengan $\mathrm{P}$ akan 
meningkatkan pertumbuhan tanaman.

Kalium akan membantu anabolisme zat pati dan memacu terbuntuknya jaringan meristem (Nyakpa, dkk, 1998).

\section{Jumlah Rumpun}

Dari hasil analisis anova yang dilanjutkan dengan uji Duncans 5\% didapatkan bahwa tidak terdapat interaksi nyata antara perlakuan lama perendaman auxin alami dan dosis pemupukan NPK untuk variabel jumlah batang bawang merah per rumpun, namun analisis pada masing-masing faktor perendaman (D) dan pemupukan (P) menunjukkan perbedaan nyata pada pengamatan pada semua umur pengamatan hingga 35 HST. Hasil analisis jumlah batang per rumpun pada umur hingga 35 HST disajikan pada Tabel 2.

Tabel 2. Rerata Jumlah Batang per Rumpun pada Perlakuan Perendaman Auxin Alami dan Pemupukan NPK

\begin{tabular}{ccccc}
\hline \multirow{2}{*}{ Perlakuan } & \multicolumn{4}{c}{ Jumlah Batang per Rumpun (HST) } \\
& 15 & 21 & 28 & 35 \\
\hline & & & & \\
D0 & $5,11 \mathrm{~b}$ & $6,78 \mathrm{~b}$ & $7,00 \mathrm{a}$ & $8,44 \mathrm{ab}$ \\
D1 & $4,78 \mathrm{~b}$ & $6,67 \mathrm{~b}$ & $7,00 \mathrm{a}$ & $8,33 \mathrm{ab}$ \\
D2 & $4,44 \mathrm{ab}$ & $6,11 \mathrm{ab}$ & $6,33 \mathrm{a}$ & $9,00 \mathrm{~b}$ \\
D3 & $4,11 \mathrm{a}$ & $5,67 \mathrm{a}$ & $6,56 \mathrm{a}$ & $7,33 \mathrm{a}$ \\
D4 & $4,78 \mathrm{ab}$ & $6,22 \mathrm{ab}$ & $6,44 \mathrm{a}$ & $8,00 \mathrm{ab}$ \\
& & & & \\
P1 & $4,27 \mathrm{a}$ & $5,60 \mathrm{a}$ & $5,87 \mathrm{a}$ & $7,53 \mathrm{a}$ \\
P2 & $4,67 \mathrm{a}$ & $6,93 \mathrm{~b}$ & $7,33 \mathrm{~b}$ & $8,87 \mathrm{~b}$ \\
P3 & $4,80 \mathrm{a}$ & $6,33 \mathrm{~b}$ & $6,80 \mathrm{~b}$ & $8,27 \mathrm{ab}$ \\
\hline
\end{tabular}

Keterangan : Angka yang didampingi huruf sama pada kolom yang sama tidak berbeda dengan uji Duncans $\alpha=0,05$

Hasil terbaik yaitu perendaman selama 1 jam (D2) sebelum tanam pada umur 35 HST adalah 9.00 batang per rumpun (Tabel 2). Penelitian Napitupulu (2010) menyatakan bahwa dosis pupuk NK mempunyai pengaruh pada pertumbuhan bawang merah. Interaksinya berpengaruh nyata pada peningkatan tinggi tanaman bawang merah. Nitrogen berfungsi dalam pembentukan zat pembangun. Kekurangan nitrogen berpengaruh dalam pembatasan pembentukan sel tanaman. Hal ini dapat menjawab mengapa dengan memberikan pemupukan pada tanaman bawang 
merah akan meningkatkan jumlah rumpun.

\section{Jumlah Umbi dan Diameter Umbi}

Variabel panen yang diamati adalah pengamatan penghitungan jumlah umbi dan pengukuran diameter umbi, pengamatan bobot basah dan bobot kering konsumsi (Tabel 3). Pengamatan panen dilakukan pada umur 68 HST. Hasil analisis ragam terhadap Jumlah Umbi bawang merah didapatkan bahwa terdapat interaksi nyata antara faktor perlakuan laman perendaman auxin alami (D) dan dosis pemupukan NPK (P). Pada variabel diameter umbi terdapat interaksi nyata berdasarkan analisis ragam. Analisis beda antar perlakuan untuk variabel jumlah umbi dan diameter umbi saat panen menggunakan uji Duncans 5\%.

Tabel 3.Rerata Jumlah Umbi dan Diameter Umbi Saat Panen

\begin{tabular}{ccc}
\hline Perlakuan & JumlahUmbi & Diameter Umbi $(\mathrm{mm})$ \\
\hline D0P1 & $16,00 \mathrm{a}$ & $28,93 \mathrm{c}$ \\
D0P2 & $20,33 \mathrm{ab}$ & $27,40 \mathrm{bc}$ \\
D0P3 & $23,67 \mathrm{~b}$ & $24,93 \mathrm{~b}$ \\
D1P1 & $20,33 \mathrm{ab}$ & $25,83 \mathrm{bc}$ \\
D1P2 & $18,67 \mathrm{a}$ & $21,77 \mathrm{a}$ \\
D1P3 & $21,67 \mathrm{~b}$ & $23,03 \mathrm{ab}$ \\
D2P1 & $21,00 \mathrm{~b}$ & $22,47 \mathrm{ab}$ \\
D2P2 & $20,33 \mathrm{~b}$ & $27,53 \mathrm{c}$ \\
D2P3 & $17,67 \mathrm{a}$ & $24,97 \mathrm{~b}$ \\
D3P1 & $19,67 \mathrm{ab}$ & $23,03 \mathrm{ab}$ \\
D3P2 & $24,00 \mathrm{~b}$ & $22,47 \mathrm{ab}$ \\
D3P3 & $20,00 \mathrm{ab}$ & $25,97 \mathrm{bc}$ \\
D4P1 & $19,00 \mathrm{ab}$ & $22,47 \mathrm{ab}$ \\
D4P2 & $24,67 \mathrm{~b}$ & $30,40 \mathrm{c}$ \\
D4P3 & $18,33 \mathrm{a}$ & $24,03 \mathrm{~b}$ \\
\hline
\end{tabular}

Keterangan : Angka yang didampingi huruf sama pada kolom yang sama tidak berbeda dengan uji Duncans $\alpha=0,05$

Pada Tabel 3 dapat dilihat bahwa perlakuan terbaik untuk variabel diameter umbi adalah kombinasi D4P2 yaitu perendaman selama 2 jam dengan pemupukan dosis $200 \mathrm{~kg} / \mathrm{ha}$ (D4P2). Nilai terbaiknya untuk jumlah umbi per rumpun adalah adalah 24,67 umbi dan untuk diameter yang terbaik adalah $30,40 \mathrm{~mm}$ pada perlakuan kombinasi D4P2. Penelitian oleh Supariadi (2017) menyatakan bahwa pemupukan NPK dapat meningkatkan hasil tanaman 
bawang merah. Dikatakan bahwa tersedianya unsur hara NPK berpengaruh terhadap pertumbuhan umbi bawang merah. Pemberian $\mathrm{N}$ secara optimal akan memperbaiki pertumbuhan tanaman, sintesa protein, pembentukan klorofil dan meningkatkan jumlah daun. Unsur $P$ berfungsi merangsang pertumbuhan akar sehingga meningkatkan pertambahan jumlah umbi, unsur $\mathrm{K}$ akan membanru pembentukan pati dan mentranslokasikannya ke dalam tubuh tanaman.

\section{Bobot Basah dan Bobot Kering Konsumsi}

Analisis varian terhadap variabel bobot basah bawang merah didapatkan bahwa tidak terdapat interaksi nyata antara perlakuan lama peredaman auxin alami dan dosis pemupukan. Namun analisis terhadap masing-masing faktor perlakuan yaitu lama perendaman berpengaruh nyata pada variabel bobot umbi basah demikian pula terhadap variabel dosis pemupukan NPK terdapat pengaruh yang nyata.

Tidak terdapat interaksi nyata antara lama perendaman dan dosis pemupukan terhadap bobot kering umbi bawang merah per rumpun, tertapi terdapat pengaruh nyata pada masing- masing faktor perlakuan.

Tabel 4 memperlihatkan hasil analisis beda antar perlakuan dengan menggunakan analisis Duncans $5 \%$. Perlakuan terbaik pada variabel bobot basah umbi/rumpun didapatkan pada perlakuan D4 yaitu perendaman dengan waktu 2 jam. Perlakuan pemupukan yang terbaik adalah dosis P3 yaitu pemupukan $300 \mathrm{~kg}$ NPK/ha. Pada variabel bobot kering umbi konsumsi bahwa perlakuan terbaik adalah D4 (perendaman selama 2 jam), demikian pula untuk perlakuan pemupukan yang terbaik adalah pemupukan dengan 300 kg NPK/ha. Menurut Kalwia (2015) bahwa penggunaan pupuk kalium berpengaruh pada pertumbuhan dan hasil tanaman bawang merah Lembah Palu. Hasil penelitiannya memberikan hasil bahwa jumlah umbi bawang merah per rumpun dipengaruhi secara nyata pada semua perlakuan. Sedangkan perlakuan umbi dan dosis pupuk kalium berpengaruh nyata pada diameter umbi, tetapi interaksi antara lama perendaman dan pupuk $\mathrm{K}$ tidak berpengaruh nyata terhadap ukuran umbi. Menurut Eliza (2016), pembentukan tunas dan diferensiasi berlangsung apabila terdapat interaksi auksin dan sitokinin lebih besar daripada auksin. Pemberian air kelapa konsentrasi $600 \mathrm{cc} / \mathrm{l}$ sekali 
pemberian berpengaruh terhadap

pertumbuhan vegetatif benih cengkeh.

Tabel 4. Rerata Bobot Basah dan Bobot Kering Konsumsi Umbi Bawang Merah

\begin{tabular}{lcc}
\hline \multicolumn{1}{c}{ Perlakuan } & $\begin{array}{c}\text { Bobot Basah Per Rumpun } \\
\text { (gram) }\end{array}$ & $\begin{array}{c}\text { Bobot Kering Per Rumpun } \\
\text { (gram) }\end{array}$ \\
\hline D0 (Tanpa Perendaman) & $269 \mathrm{a}$ & $175 \mathrm{a}$ \\
D1 (Perendaman 0,5 jam) & $309 \mathrm{~b}$ & $201 \mathrm{~b}$ \\
D2 (Perendaman 1,0 jam) & $306 \mathrm{~b}$ & $199 \mathrm{~b}$ \\
D3 (Perendaman 1,5 jam) & $311 \mathrm{~b}$ & $202 \mathrm{~b}$ \\
D4 (Perendaman 2,0 jam) & $365 \mathrm{c}$ & $237 \mathrm{c}$ \\
& & \\
P1 (100 kg/ha) & $249 \mathrm{a}$ & $162 \mathrm{a}$ \\
P2 (200 kg/ha) & $303 \mathrm{~b}$ & $197 \mathrm{~b}$ \\
P3 (300 kg/ha) & $385 \mathrm{c}$ & $250 \mathrm{c}$ \\
\hline
\end{tabular}

Keterangan : Angka yang didampingi huruf sama pada kolom yang samatidak berbeda dengan uji Duncans $\alpha=0,05$

\section{KESIMPULAN}

Perlakuan kombinasi terbaik adalah D4P2 (lama perendaman 2 jam dan dosis NPK $200 \mathrm{~kg} / \mathrm{ha})$ untuk variabel jumlah umbi dan diameter umbi.

\section{UCAPAN TERIMAKASIH}

Ucapan terimakasih disampaikan kepada Dirjen Dikti atas pendanaan hibah skema PDP dengan dana DRPM, pula kepada Rektor Unisba yang telah memberi kesempatan melaksanakan penelitian ini.

\section{DAFTAR PUSTAKA}

Amin, M.R., M.K.. Hasan, Q. Naher M.A. Hossain \& Z.U. Noor. 2007. Response of Onion to NPKS Fertilizers in Low Ganges River Flood Plain Soil. Int. J. Sustain. Crop Prod. 2 (1): 11-14.

BPS. 2018. Statistik Tanaman Sayuran dan Buah-buahan Semusim Indonesia. BPS Statistic Indonesia.

Eliza, M., Yudarfis, H. Idris dan I. Darwa. 2016. Pengaruh Pemberian Air Kelapa dan Frekuensi Pemberiannya Terhadap Pertumbuhan Benih Tanaman cengkeh (Syzygium aromaticum). Bul. Littro. 27 (2).

Hasibuan, B. E. 2010. Pupuk dan Pemupukan. USU-Press, Medan.

Islam, M.K., M.F. Alam \& A.K.M.R. 
Islam. 2007. Growth and Yield Response of Onion (Allium cepa L.) Genotypes to Different Levels of Fertilizer. Bangladesh J. Bot. 36 (1): 33-38.

Juhanda, Y. N. \& Ermawati. 2013. Pengaruh Skarifikasi pada Pola Imbibisi dan Perkecambahan Benih Saga Manis (Abruss precatorius L.). J. Agrotek Tropika. 1 (1): 45-49.

Kalwia, H.Y.U., H. Barus, I. S. Madauna. 2015. Pengaruh Ukuran Umbi dan Dosis Kalium terhadap Pertumbuhan dan Hasil produksi Bawang merah (Allium ascalonicum L.) Varietas Lembah Palu. e-J. Agrotekbis. 3 (6): 655661.

Mahadi, I. 2011. Pematahan Dormansi Biji Kenerak (Ganiothalamus umbrosus) Menggunakan Hormon 2,4 D dan BAP Secara Mikropropagasi. Sagu. 10 (1) : 20-23.

Napitupulu, D. dan L. Winarto 2010. Pengaruh Pemberian Pupuk N dan $\mathrm{K}$ terhadap Pertumbuhan dan Produksi Bawang Merah .J. Hort. 20 (1): 27-33.

Nyakpa, M.Y., A.M. Pulung., A.G. Amrah., A. Munawar., G. B. Hong dan N. Hakim. 1998. Kesuburan Tanah. Universitas Lampung. Banda.r Lampung.

Rajiman. 2018. Pengaruh Zat Pengatur Tumbuh (ZPT) Alami terhadap Hasil dan Kualitas Bawang Merah. 2 (1).

Risva, A.H., Tohari, N.H.U. Sri. 2014. Takaran Pupuk Nitrogen dan Silika terhadap Pertumbuhan
Awal (Saccharum officinarum L) pada Inceptisol. Vegetalika. 3: 3544.

Sumarni, N, R. Rosliani dan R.S. Basuki. 2012. Respons Pertumbuhan, Hasil Umbi, dan Serapan Hara NPK Tanaman Bawang Merah terhadap Berbagai Dosis Pemupukan NPK pada Tanah Alluvial. J. Hort. 22 (4): 366-375.

Supariadi, H. Yetti dan S.Yoseva. 2017. Pengaruh Pemberian Pupuk Kandang dan Pupuk NPK terhadap Pertumbuhan dan Produksi Tanaman Bawang merah (Allium ascalonicum L.). JOM Faperta. 4 (1).

Yuliarti, N. 2007. Media Tanam Pupuk untuk Anthurium Daun. Agromedia Pustaka. Jakarta. 